\title{
Influence of mycotoxin zearalenone and its derivatives (alpha and beta zearalenol) on apoptosis and proliferation of cultured granulosa cells from equine ovaries
}

\author{
Fiorenza Minervini*1, Alessandra Giannoccaro1 ${ }^{1}$, Francesca Fornelli ${ }^{1}$, \\ Maria Elena Dell'Aquila ${ }^{2}$, Paolo Minoia ${ }^{2,3}$ and Angelo Visconti ${ }^{1}$
}

\author{
Address: ${ }^{1}$ Institute of Sciences of Food Production (ISPA), National Research Council (CNR), Via Amendola 122/O, 70124 Bari, Italy, ${ }^{2}$ Department \\ of Animal Production, University of Bari, Strada Provinciale per Casamassima Km 3, 70010 Valenzano Bari, Italy and ${ }^{3}$ Deceased \\ Email: Fiorenza Minervini* - fiorenza.minervini@ispa.cnr.it; Alessandra Giannoccaro - ale.g.vet@fastwebnet.it; \\ Francesca Fornelli - francescafornelli@libero.it; Maria Elena Dell'Aquila - e.dellaquila@veterinaria.uniba.it; \\ Paolo Minoia - p.minoia@veterinaria.uniba.it; Angelo Visconti - angelo.visconti@ispa.cnr.it \\ * Corresponding author
}

Published: 30 November 2006

Reproductive Biology and Endocrinology 2006, 4:62 doi:10.1186/1477-7827-4-62

This article is available from: http://www.rbej.com/content/4/I/62

(c) 2006 Minervini et al; licensee BioMed Central Ltd.

This is an Open Access article distributed under the terms of the Creative Commons Attribution License (http://creativecommons.org/licenses/by/2.0), which permits unrestricted use, distribution, and reproduction in any medium, provided the original work is properly cited.
Received: 26 July 2006

Accepted: 30 November 2006

\begin{abstract}
Background: The mycotoxin zearalenone (ZEA) and its derivatives, alpha and beta-zearalenol (alpha and beta-ZOL), synthesized by genera Fusarium, often occur as contaminants in cereal grains and animal feeds. The importance of ZEA on reproductive disorders is well known in domestic animals species, particularly in swine and cattle. In the horse, limited data are available to date on the influence of dietary exposure to ZEA on reproductive health and on its in vitro effects on reproductive cells. The aim of this study was to evaluate the effects of ZEA and its derivatives, alpha and beta-ZOL, on granulosa cells (GCs) from the ovaries of cycling mares.
\end{abstract}

Methods: The cell proliferation was evaluated by using the 3-(4,5-dimethylthiazol-2-yl)-2,5diphenyltetrazolium bromide (MTT) test after 3 days exposure at different concentrations of ZEA and its derivatives (from I $\times 10-7$ to 0.1 microM). The apoptosis induction was evaluated after I day exposure, by DNA analysis using flow cytometry.

Results: An increase in cell proliferation with respect to the control was observed in the presence of ZEA at I $\times 10-3$ and I $\times 10-4$ microM and apoptosis was induced by all mycotoxins at different concentrations.

Conclusion: The simultaneous presence of apoptosis and proliferation in GC cultures treated with zearalenones could indicate that these mycotoxins could be effective in inducing follicular atresia. These effects of zearalenones may result from both direct interaction with oestrogenreceptors as well as interaction with the enzymes 3alpha (beta)-hydroxysteroid dehydrogenase (HSD), involved in the synthesis and metabolism of endogenous steroid hormones. These cellular disturbances, described for the first time in equine GCs cultured in vitro, could be hypothesized as referred to reproductive failures of unknown ethiology in the mare. 


\section{Background}

Many different mycotoxins have been recognized and isolated from a variety of Fusarium moulds and some of the disease states, caused by consumption of cereals containing these toxins in domestic animals as well as in humans, have been called fusariotoxicoses. Zearalenone (ZEA) and related compounds $\alpha$ and $\beta$ zearalenol ( $\alpha$ and $\beta$-ZOL) and $\alpha$ and $\beta$ zearalanol ( $\alpha$ and $\beta$-ZAL) are synthesized by a number of species of Fusarium such as $F$. graminearum, $F$. tricinctum, F. moniliforme and F. oxysporum [1].

Sensitivity to the effects of mycotoxins is related to species-dependent biotransformation pathways. Zearalenone is metabolized via two pathways in hepatocytes and intestinal cells, namely conjugation with glucuronic acid and reduction to $\alpha$ and $\beta$-ZOL by $3 \alpha(\beta)$-hydroxysteroid dehydrogenase (HSD) [2-4]. These reactions show similarities to processes in steroid metabolism because HSDs catalyse oxidation/reduction reactions in the synthesis and inactivation of steroid hormones [4].

The influences of ZEA on reproductive structural and functional parameters are well recognized. Of all domestic species, swine is the most sensitive species, followed by ruminants. Birds are the most resistant species [3]. The high sensitivity of pigs to ZEA-mediated oestrogenic effects can be related to ZEA bio-activation prevalently into $\alpha$-ZOL. The higher estrogenicity of $\alpha$-ZOL is related to its stronger relative binding affinity to the cytoplasmic oestrogenic receptor than $\beta-\mathrm{ZOL}$, as described in the rat uterus [5].

Of all stages of maturity, the pre-pubertal gilt is the most sensitive to ZEA [6]. The changes induced by ZEA depend on the time of administration, in relation to the oestrous cycle, and on the administered dose [6]. A vulvovaginitis syndrome in young female swine and anaestrus induction in the mature sow, have been reported [7]. In extreme cases, rectal and vaginal prolapses occurred. Several atresic follicles are present on ovaries and degeneration of oocytes occurs [8-10].

Concerning the equine species, the effects of ZEA have only been demonstrated in a few cases. A field outbreak of ZEA mycotoxicosis in horses was associated with corn screenings containing approximately $2.6 \mathrm{mg} / \mathrm{Kg}$ of ZEA [11]. Raymond et al. [12,13] reported the influence of ZEA, administered at a low dose, on performance and hematological parameters. No disturbances on reproductive functions were reported for cycling mares after exposure of $1 \mathrm{mg} / \mathrm{Kg}$ of ZEA in the feed [14]. However, these levels are also ineffective on sensitive species, such as swine [7]. The limited number of reports on ZEA-related clinical symptoms in the horse could not exclude the involvement of this feed contaminant in hypo-fertility cases. No data have been reported to date concerning the pharmaco-kinesis and metabolism of ZEA in the horse.

In relation with the high incidence of ZEA-related reproductive failures in other species [15] and considering the difficulties in conducting in vivo studies on reproductive influence of ZEA on system in the horse, the purpose of this paper was to investigate the effects of ZEA and its derivatives, $\alpha$ and $\beta$-ZOL, on granulosa cells (GCs) collected from mare ovaries during the breeding season. It has been demonstrated that mural GCs are strictly involved in the control of oocyte growth and maturational competence [16] and are a sensitive target of xenoestrogen substances [17].

Premature follicular atresia is a recognized ZEA-induced consequence associated with either natural or experimental contamination [8-10]. The aim of this work was to use flow cytometric analysis in order to evaluate the atretic process in cultured GCs after treatment with zearalenones. Analysis of DNA content by flow cytometry provides a means of looking at early apoptosis and atresia as well as cell cycle perturbation and accumulation or depletion of cells in particular phases. With this method, apoptotic cells, containing less DNA than normal diploid cells, exhibit reduced fluorescence and are recorded as a sub- $\mathrm{G}_{0}$ peak. This method has been reported to date in porcine, bovine, ovine and rat follicles [18-22]. Atresia consists of a dynamic equilibrium between GC division, differentiation and death and simultaneous apoptosis and mitosis processes occur [23]. For this reason, an evaluation of GC proliferation was carried out using colorimetric (MTT test) and flow cytometric methods.

\section{Methods \\ Chemicals}

Zearalenone (ZEA, purity 99\%), $\alpha$-zearalenol ( $\alpha$-ZOL, purity 98\%), $\beta$-zearalenol ( $\beta$-ZOL, purity 95\%), Dulbecco's Modified Eagle's Medium (DMEM), Ham F-12, sodium bicarbonate, gentamycin, collagenase, dimethylsulphoxide (DMSO), Trypan blue solution, foetal bovine serum (FBS), Propidium Iodide solution (PI), trypsinEDTA solution and MTT were all purchased from SigmaAldrich (Italy). 2-Propanol was purchased from Baker (Holland), Ficoll-Paque Plus from Pharmacia Biotech, Uppsala (Sweden). Nonided P 40 substitute solution was purchased from Fluka (Italy)

\section{Collection of GCs from mare ovaries}

The study was performed during the breeding season (2004-2005). Ovaries of cyclic mares at unknown stages of the oestrous cycle were obtained from an abattoir 30 $\mathrm{Km}$ from the laboratory. Ovaries $(\mathrm{n}=102)$ were placed in physiological saline $(9 \mathrm{~g} \mathrm{NaCl}$ containing $40 \mathrm{mg} / \mathrm{L}$ gentamycin sulphate) within $30 \mathrm{~min}$ of slaughter and were 
transported to the laboratory in thermal containers set at $30^{\circ} \mathrm{C}$ ( $1 \mathrm{~h}$ transport). All antral (subordinate) follicles $(0.5$ to $2.5 \mathrm{~cm})$ that were visible on the ovarian surface were opened with a scalpel blade and the GC layer was scraped with a curette [24]. Granulosa cells were flushed from the curette into individual Petri dishes using HEPESbuffered tissue culture medium (medium 199, Gibco BRL) supplemented with 10\% FBS. The time between follicle scraping and starting of GC cultures was less than $2 \mathrm{~h}$ and the total time between slaughter and culture ranged between 3 and $5 \mathrm{~h}$.

\section{GC cultures}

After collection as pools from mare ovaries, GCs were washed twice in serum-free medium (DMEM \ Ham F-12 with $0.12 \mathrm{mM}$ gentamycin, $2.0 \mathrm{mM}$ glutamine and 38.5 $\mathrm{mM}$ sodium bicarbonate), recovered by centrifugation ( 5 min at $200 \times g$ ) and re-suspended in the same medium containing $1.25 \mathrm{mg} / \mathrm{ml}$ of collagenase to disperse clumping of the cells [25]. Then, the cells were layered onto $3 \mathrm{ml}$ of Ficoll-Paque Plus (Pharmacia Biotech, Uppsala, Sweden) and centrifuged (10 $\left.\mathrm{min}, 1500 \times g, 4^{\circ} \mathrm{C}\right)$. Finally, cells were re-suspended in medium containing 10\% FBS. Cell viability was determined by the Trypan blue dye exclusion test. In 15 experiments the viability ranged from 30 to $65 \%$ with a mean value of $40 \%$. The GC pools were used to evaluate the cellular proliferation by the MTT test and the apoptosis induction by DNA analysis with flow cytometry.

\section{Preparation of test substances}

The mycotoxins were solubilized as stock solution at a concentration of $10 \mathrm{mM}$ in DMSO and then diluted in a 1:1 ( $\mathrm{v} \backslash \mathrm{v})$ mixture of DMEM and Ham F-12, containing $0.12 \mathrm{mM}$ gentamycin, $2.0 \mathrm{mM}$ glutamine, $38.5 \mathrm{mM}$ sodium bicarbonate and 10\% FBS. Mycotoxin serial dilutions $(1: 10)$ were prepared at concentrations ranging from $1 \times 10^{-7}$ to $0.1 \mu \mathrm{M}$. The concentration range used in this study corresponded to the active level $(25 \mathrm{ng} / \mathrm{ml}$ ) on GCs reported in bitch [26].

\section{Evaluation of cell proliferation by MTT test}

At the beginning of each experiment, GCs were seeded in 96 multi-well plates (Iwaki, Japan) at $3 \times 10^{4}$ cells/well in $200 \mu \mathrm{l}$ of medium containing $10 \%$ FBS. The cells were allowed to attach for $24 \mathrm{~h}$, the medium was changed with fresh medium and each concentration of test compound was added in triplicate wells. A negative control (without mycotoxin) was included in each plate. After 3 days of incubation, cell proliferation was measured using the MTT test, as described previously [27]. The cleavage of 3(4,5-dimethylthiazol-2-yl)-2,5-diphenyltetrazolium bromide (MTT) to a blue coloured product (formazan), which is indicative of mitochondrial succinate-dehydrogenase activity in viable cells, was quantified by spectro- photometric analysis. Absorbance was measured at 580 nm in a plate reader (ELISA Reader Multiskan MS Plus MK II Labsystem, Finland). Four experiments were performed for each mycotoxin subtype and dosage regime.

\section{DNA analysis by flow cytometry}

The analysis of DNA by flow cytometry was performed following the method described by different authors [1822]. At the beginning of each experiment, GCs were seeded in 24 multi-well plates (Iwaki, Japan) at $5 \times$ $10^{6}$ cells/well in $1 \mathrm{ml}$ of medium and each concentration of test compound was added in duplicate wells. A negative control (without mycotoxin) was included in each plate. After 24 hr of incubation, cells were detached by trypsinization and the pellets were obtained by centrifugation ( 5 $\min$ at $200 \times g)$. Cells were fixed in $96 \%$ cold ethanol ($20^{\circ} \mathrm{C}$ ) and in cold saline solution containing $1.10 \mathrm{~g} \backslash \mathrm{l}$ glucose, $8 \mathrm{~g} \backslash \mathrm{L} \mathrm{NaCl}, 0.40 \mathrm{~g} \backslash \mathrm{L} \mathrm{KCl}, 0.20 \mathrm{~g} \backslash \mathrm{L} \mathrm{Na}_{2} \mathrm{HPO}_{4}, 0.15$ $\mathrm{g} \backslash \mathrm{L} \mathrm{KH}{ }_{2} \mathrm{PO}_{4}$ and $0.20 \mathrm{~g} \backslash \mathrm{L}$ EDTA. Subsequently, cells were centrifuged at $300 \times \mathrm{g}$ for $5 \mathrm{~min}$, re-suspended in $0.5 \mathrm{ml}$ of cold PBS at $4^{\circ} \mathrm{C}$ and stained for at least $15 \mathrm{~min}$ with 25 $\mu \mathrm{g} / \mathrm{ml}$ PI in $0.1 \%$ citrate sodium, RNase $(1 \mathrm{mg} / \mathrm{ml})$ and Nonided P 40 substitute solution (1\%). Cells were then analysed by FACSCalibur flow cytometry (Becton Dickinson). Propidium iodide fluorescence was obtained using linear (FL-2 584-642 mm) amplification. At least 10,000 events were recorded for each sample. Cell cycle analysis was calculated by rectangular fitting (MODIFIT software, Becton-Dickinson, Milan, Italy), using 1024 channels which produced histograms with a single $G_{0} / G_{1}$ peak at channel 200 when DNA was diploid, an S-peak between channels 200 and 400 when DNA was replicating, a $\mathrm{G}_{2} / \mathrm{M}$ peak at channels 400 when DNA was tetraploid and a sub$\mathrm{G}_{0}$ peak, between 100 and 200 when DNA was hypodiploid or damaged. The small coefficient of variation (CV) obtained in this study was the result of the high resolution achieved by proper alignment. Four independent experiments were performed for each mycotoxin treatment regime.

\section{Statistical analysis}

All statistical analyses were performed using the GraphPad Instat Software version 2.03 (Sigma, Italy). Statistical differences between mean values and the control were evaluated by analysis of variance (ANOVA) followed by the Dunn multiple comparison post test.

\section{Results \\ Cell proliferation}

At levels of $1 \times 10^{-4}$ and $1 \times 10^{-3} \mu \mathrm{M}$, ZEA induced a statistically significant increase in cell proliferation compared to the control ( $\mathrm{p}<0.01$ and 0.05 , respectively; Fig 1 ). The tested concentrations of $\alpha$ and $\beta$-ZOL did not induce increases in cell proliferation. High doses of ZEA and its 
metabolites demonstrated a trend towards down-regulation of GC proliferation indices.

\section{DNA analysis}

As observed in a representative experiment (Fig. 2), all mycotoxins induced apoptosis, evaluated as a sub- $\mathrm{G}_{0}$ peak, on equine GCs at different concentration levels. Alpha-zearalenol was more active and induced apoptosis at $1 \times 10^{-3} \mu \mathrm{M}\left(28 \%\right.$ of the sub- $\mathrm{G}_{0}$ peak compared to $4 \%$ observed in the control sample), following by ZEA at $1 \times$ $10^{-2} \mu \mathrm{M}\left(50 \%\right.$ of sub- $\mathrm{G}_{0}$ peak) and $\beta-Z O L$ at $1 \times 10^{-1} \mu \mathrm{M}$ (37\% of sub- $\mathrm{G}_{0}$ peak).

The percentages of GCs in $G_{0} / G_{1}$ (cells in the stationary phase), $S+G_{2} / M$ (cells in proliferation) and sub- $G_{0}$ (apoptotic cells) phases found in all experiments are shown in
Fig 3. No statistical difference was observed following treatment with zearalenones and a high variability between experiments was found. For $\alpha-Z O L$, a concomitant 2 fold increase in the sub- $G_{0}$ and $S+G_{2} / M$ peaks was observed at $1 \times 10^{-3} \mu \mathrm{M}$. The apoptotic process was induced, at low intensity (1.5 fold of increase in the sub$\mathrm{G}_{0}$ peak with respect to the control), up to $1 \times 10^{-5} \mu \mathrm{M}$. A $23 \%$ reduction of the $G_{0} / G_{1}$ phase was found after exposure to $1 \times 10^{-3} \mu \mathrm{M}$ of $\alpha$-ZOL (Fig. 3). At lower concentrations, the cell cycle was similar to the control. Concerning ZEA, at $1 \times 10^{-2} \mu \mathrm{M}$ the sub- $G_{0}$ and $S+G_{2} / M$ phases increased simultaneously 2.7 and 2 fold, respectively. A two fold increase in the sub- $\mathrm{G}_{0}$ peak continued until $1 \times$ $10^{-5} \mu \mathrm{M}$ of ZEA. A $24 \%$ reduction in the $\mathrm{G}_{0} / \mathrm{G}_{1}$ peak was observed at $1 \times 10^{-2} \mu \mathrm{M}$ of ZEA (Fig 3). Other concentrations of ZEA did not modify the cell cycle of GCs com-

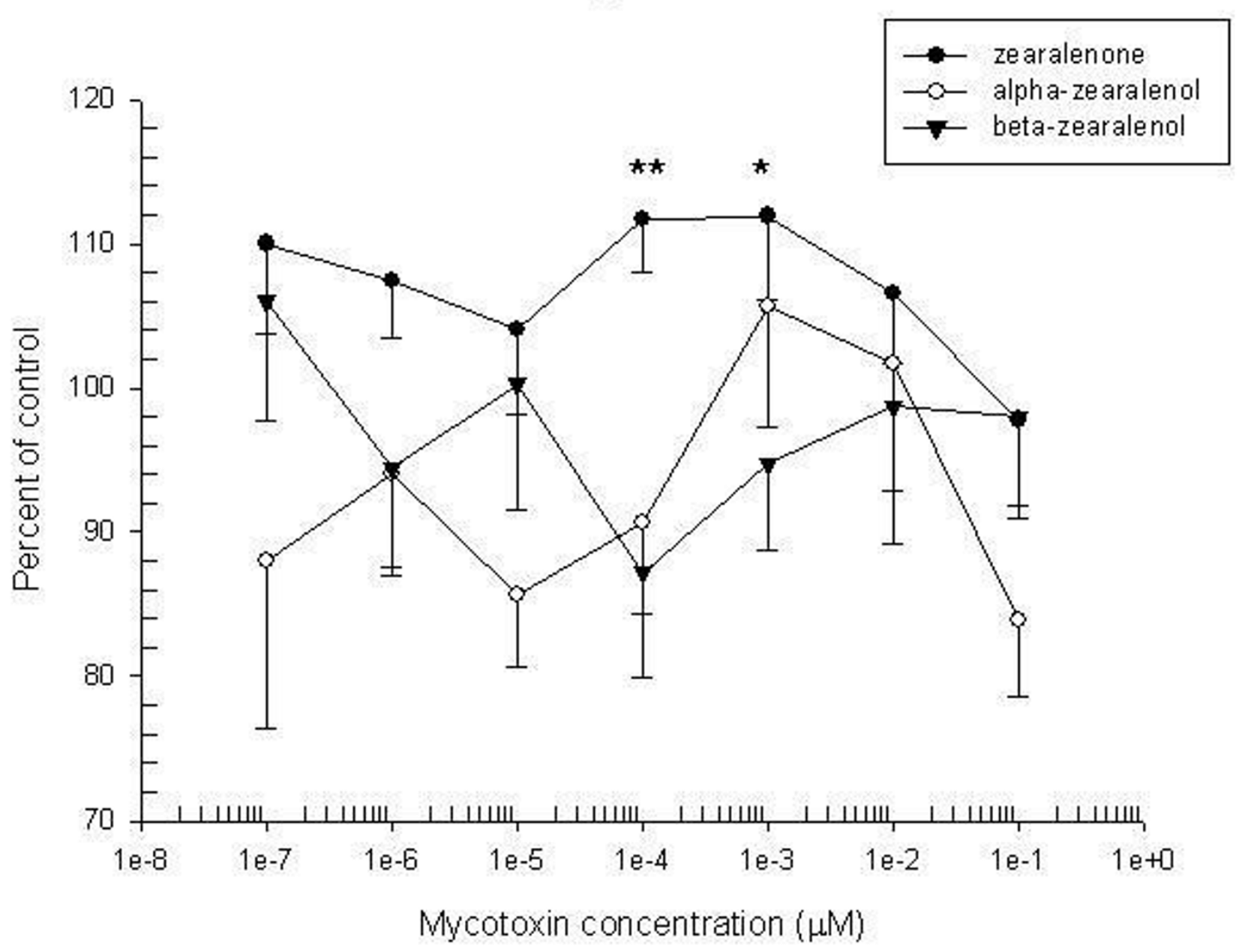

Figure I

Equine granulosa cell proliferation by MTT test after 72 hours. Data represent mean \pm SEM of four experiments (each concentration is tested in triplicate). $* p<0.05$ and $* * p<0.01$ significantly different from control values evaluated by ANOVA followed by the Dunn multiple comparison post test. 

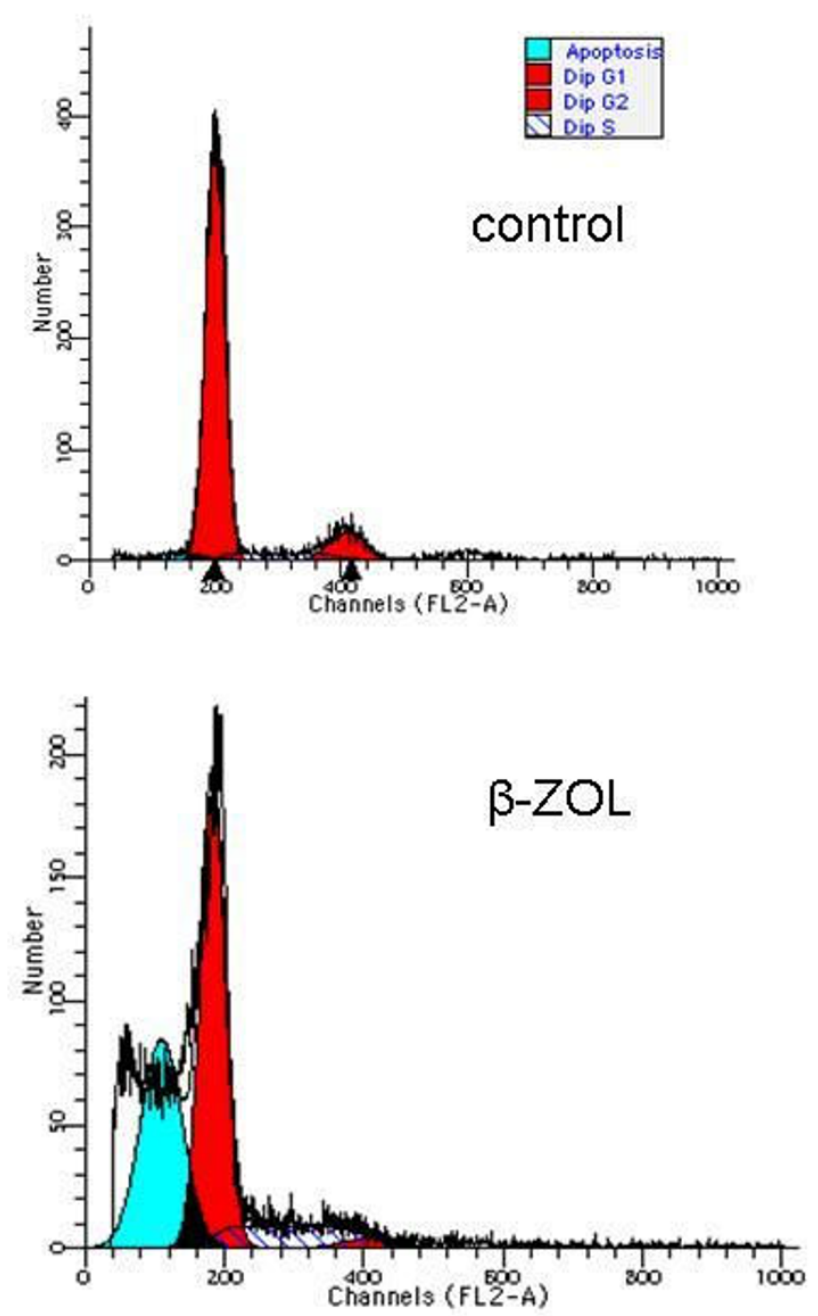
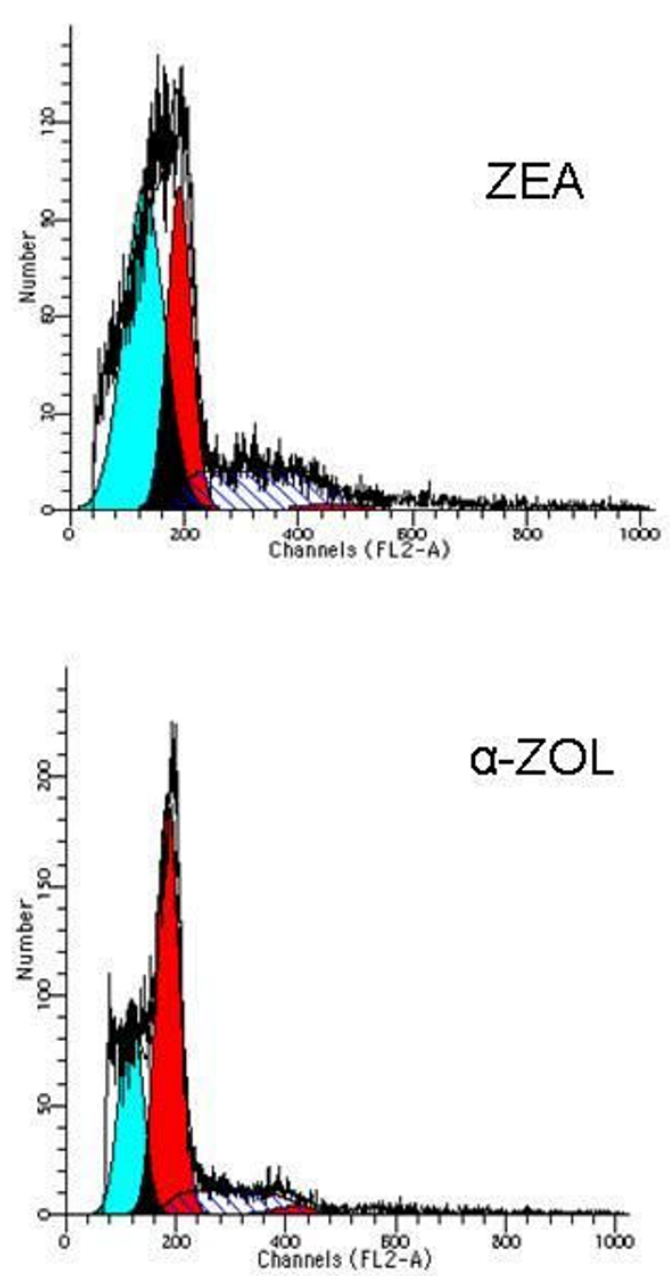

Figure 2

A representative DNA analysis of equine granulosa cells exposed to zearalenone and its derivatives using flow cytometry.

pared to the control. Concerning $\beta-\mathrm{ZOL}$, the maximum increase ( 2 fold) in the sub- $G_{0}$ peak was observed at the highest concentration and continued, at low intensity (1.2 fold of increase), up to $1 \times 10^{-2} \mu \mathrm{M}$. No variations to other phases of the cell cycle were observed in the presence of $\beta$ ZOL (Fig 3). Other concentrations of $\beta$-ZOL did not modify the cell cycle of GCs compared to the control.

\section{Discussion}

An increase in cell proliferation of equine GCs was observed using the MTT test in the presence of $1 \times 10^{-4}$ and $1 \times 10^{-3} \mu \mathrm{M}$ of ZEA. High doses of ZEA and its metabolites demonstrated a trend towards down-regulation of GC proliferation indices. This increased proliferation could be the consequence both of the reduction of ZEA into $\alpha$ ZOL and the modification of ovarian steroidogenesis with accumulation of the active hormonal components related to the involvement of $3 \alpha(\beta)$-HSD, enzymes present in the ovary and GCs $[3,29]$. The HSDs have also been claimed to be important factors in ovarian follicular development and their inhibition may promote follicular atresia, since abnormalities in the androgen, progestin and oestrogen metabolism can lead to ovarian dysfunction $[3,28]$. Zearalenone and its derivatives induced apoptotic processes within equine CGs at different concentrations. The mean intensity of apoptosis induced by ZEA was greater than that caused by $\alpha-Z O L$, probably derived from the combined effect exerted by both mycotoxins metabolized by 

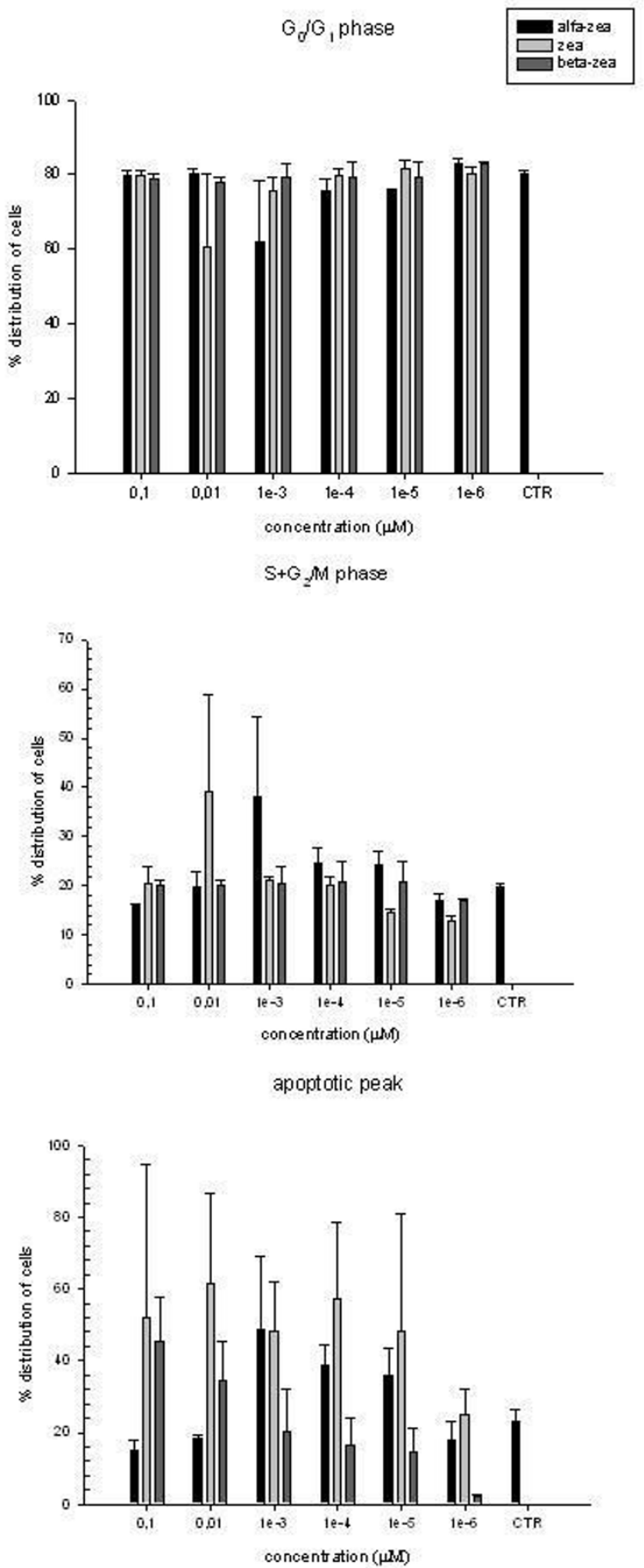

Figure 3

Modification of cell cycle of equine granulosa cells following exposure to zearalenones. Data represent mean \pm standard deviation of four experiments.
HSD in GCs, as reported previously [29]. Beta-zearalenol was less active than other mycotoxins because it induced apoptosis only at the highest concentration.

In this study, ZEA and its derivatives did not induce statistically different modifications of cell distribution in different phases of the cell cycle. However, it should be noted a trend in growth increasing, evaluated as $\mathrm{S}+\mathrm{G}_{2} / \mathrm{M}$ proliferation peak, that was affected by $1 \times 10^{-2}$ and $1 \times 10^{-3} \mu \mathrm{M}$ of ZEA and $\alpha$-ZOL, respectively. The observed variability could be related to the different levels of HSDs in GS cultured in each experiment, as reported by other authors [30]. In addition, seasonal (light, temperature), environmental (stress, diet) and hormonal factors (including the enzymatic contents) as well as the holding time and temperature can influence the variability observed during experiments carried out with equine GCs [31]. Though no statistical differences were found in our experiments, simultaneous increases in the sub- $\mathrm{G}_{0}$ and $S+\mathrm{G}_{2} / \mathrm{M}$ peaks indicate a simultaneous occurrence of apoptosis and the proliferation process after exposure with ZEA and $\alpha$-ZOL. This dynamic equilibrium between division, differentiation and death was found by Pedersen et al. [32] in atretic follicles. The simultaneous occurrence of proliferation and apoptosis was studied by Quirk et al [33,34] in bovine GCs. These authors reported that oestradiol, an important intraovarian growth, differentiation and survival factor, increases the progression from $G_{0} / G_{1}$ to $S$ phase, the percentage of cells in $S$ phase and, consequently, the percentage of DNA synthesizing cells and that this cell cycle progression is mediated by the oestrogen receptor [33]. Granulosa cells may be most susceptible to apoptosis at the transition from $G_{1}$ to $S$ phase [34]. We hypothesize that zearalenones, oestrogen-like substances, can act with a similar mechanism on equine GCs and can induce proliferation and apoptotic process.

Follicular degeneration, or atresia, is the result of an apoptotic process defined as a sequence of programmed intracellular events leading to cell death [20]. The first signs of atresia are evidenced as the degeneration of the antral GCs, whereas the oocyte is affected in the last stages of atresia $[35,36]$. Various techniques have been adopted to measure the degree of follicular degeneration in ovaries. Few reports are available to date on apoptosis of GCs in horse. Okolski et al. [37] evaluated equine GCs for the presence of nuclear fragments they termed atretic bodies. The presence of these bodies was correlated with reduced oestrogen levels in the follicular fluid but was not correlated with the proportion of oocytes that matured in vitro [37]. Pedersen et al. [32], the first group using DNA laddering to study apoptosis in the mares, found that small follicles were more likely than large follicles to be apoptotic. These authors reported that the histological method used for determining the presence of atresia was not relia- 
ble because atretic GCs were not uniformly distributed but were observed in focal points, within areas of healthy GCs [32]. Albrizio et al. [38] investigated follicular wall apoptosis in the mare by comparing DNA laddering and the incidence of apoptotic bodies (AB) analyzed by Hoechst 33258 staining. These authors found that high rates $(80 \%)$ of typical masses of $A B$ were observed in GCs of small follicles from anoestrous mares and, with a lower incidence, in pools from regressing follicles collected from the ovaries of transitional, oestrous and dioestrous mares (30-40\%). Large pre-ovulatory follicles were totally lacking $\mathrm{AB}$. Correspondingly, the presence of DNA fragments forming the characteristic banding pattern (ladder) of apoptosis was revealed in the GCs from anoestrous mares; these fragments were not detected in the GCs from large pre-ovulatory follicles while they had an intermediate incidence in the follicles from ovaries of transitional and dioestrous mares. Dell'Aquila et al. [39] reported that GC apoptosis in the mare is related to cumulus expansion and to an increase in oocyte meiotic competence but has no effect on the proportion of meiotically competent oocytes that activate after ICSI. Subsequently, Pedersen et al. [40] detected GC apoptosis by comparing two biochemical methods, 3'-end labelling and staining with ethidium bromide then microscopic examination of GC morphology, with the established method of detecting atresia by histology. These authors concluded that the more parameters used in conjunction with each other, the more accurate was the analysis of the state of the follicle. Many studies have shown that GCs with hypodiploid DNA content are apoptotic, may represent a biochemical marker for atretic follicles in several animal species and that this method is sensitive enough to detect apoptosis in its very early stages [18-22]. Granulosa cells that have initiated chromatin cleavage are definitively non-functional and flow cytometry enables the rapid detection of cells that are undergoing the early events of apoptosis, as previously reported in porcine, bovine, ovine and rat follicles [1822]. In our experimental conditions, flow cytometry was effective and rapid for evaluating the in vitro effects of the mycotoxin on GC apoptosis in the mare. This is the first report on the use of flow cytometry to study the atretic process in mare cultured GCs.

A "mare reproductive loss syndrome (MRLS)", which occurred in Kentucky in 2001, was characterized by non etiologically defined cases of early and late-term abortions [41]. Different etiological agents were thought to be responsible for this pathology, such as ergot alkaloids, phytoestrogens or mycotoxins, caterpillar and Actinobabacillus spp[41]. The possible role of the mycotoxin ZEA as a cause of MRLS has been reviewed by Newman, 2003 [42] and Newman and Raymond, 2005 [43]. Our data integrate previous in vitro observations conducted on both the germinal and somatic compartments of ovarian follicles in animal models as well as in humans. In sows, ZEA and its hydroxylated metabolites ( $\alpha$ and $\beta$-ZOL) exerted negative effects on oocyte maturation [44] and inhibited the $\mathrm{FSH}-$, forskolin- and pregnenolone-stimulated progesterone synthesis in GCs [45]. In cattle, ZEA and its derivatives inhibited the maturation of oocytes to metaphase II and high levels of $17 \beta$-estradiol production by mural GCs were found [46]. The negative influence of ZEA was reported by Skorska-Wyswynska et al. [26] on cellular viability and morphology of cultured granulosa and internal theca cells of ovarian follicles in bitches. In human granulosa-luteal cells, ZEA was a potent inhibitor of aromatase/ $17 \beta$ HSD up to $10^{-7} \mathrm{M}$ with consequent inhibition of the conversion of androstenedione to oestradiol [17]. No in vitro studies have been previously carried out in the mare reproductive tract.

\section{Conclusion}

Equine GCs are sensitive to the effects of zearalenones, especially to $\alpha$-ZOL and ZEA. This rank of activity was in agreement to that observed in vitro for other farm animals $[45,46]$. This sensitivity of equine GCs to oestrogenic effects induced by ZEA and its derivatives emphasizes the importance of ZEA in reproductive disorders in this species. Studies are in progress to deepen understanding the mode of action of zearalenones on apoptosis and cell proliferation in GCs and the influence of zearalenones on reproductive function in the mare.

\section{Authors' contributions}

$\mathrm{FM}=$ the author responsible for conceiving the research project, interpretation of data and involved in drafting the manuscript especially concerning the mycotoxin field.

$\mathrm{AG}=$ the author responsible for designing and performing the proliferation analysis and statistical analysis

$\mathrm{FF}=$ the author responsible for designing and performing the DNA analysis and statistical analysis.

MED = the author responsible for the isolation of granulosa cells and involved in drafting the manuscript especially concerning the section on equine reproductive biology and biotechnology

$\mathrm{PM}=$ The author involved in critically revising the manuscript especially concerning equine obstetrical and gynaecological details. He died during preparation of the manuscript and we dedicate this article to his long-standing contribution to the animal reproduction field.

$\mathrm{AV}=$ the author involved in critically revising the manuscript for important intellectual content and the supervisor of the research group. 


\section{Acknowledgements}

This research was supported by a grant from the Ministero della Salute (Prog. Fin n. 132/2002) Italy; Responsible Scientist Dr. Fiorenza Minervini

The author Paolo Minoia died during the preparation of this manuscript. We dedicate this article to Prof. Minoia for his long-standing contribution to animal reproduction.

\section{References}

I. Placinta CM, D'Mello JPF, Mac Donald AMC: A review of worldwide contamination of cereal grains and animal feed with Fusarium micotoxins. Anim Feed Sci Tech 1999, 78:21-37.

2. Olsen M, Pettersson $H$, Sandholm K, Visconti A, Kiessling KH: Metabolism of zearalenone in sow intestinal mucosa in vitro. Fd Chem Toxic 1987, 29(9):68I-683.

3. Olsen M: Metabolism of zearalenone in farm animals. Fusarium: mycotoxins, taxonomy and pathogenicity 1989:167-I77.

4. Malekinejad H, Maas-Bakker R, Fink-Grenmels J: Species differences in the hepatic biotransformation of zearalenone. Vet 2006, I 72(I):96-102.

5. Katzenellenbogen BS, Katzenellenbogen JA, Mordeca D: Zearalenones: characterization of the estrogenic potencies and receptor interactions of a series of fungal $\beta$-resorcyclic acid lactones. Endocrinology 1979, 105:33-40.

6. Haschek WM, Haliburton JC: Fusarium moniliforme and zearalenone toxicoses in domestic animals. In Diagnosis of mycotoxicoses Edited by: Richard JL, Thurston JR. Martinus Nijhoff Publishers; 1896:213-235.

7. Osweiler GD: Occurrence and clinical manifestations of trichothecene toxicoses and zearalenone toxicoses. In Diagnosis of mycotoxicoses Edited by: Richard JL, Thurston JR. Martinus Nijhoff Publishers; 1986:31-42.

8. Diekman MA, Green ML: Mycotoxins and reproduction in domestic livestock. J Anim Sci 1992, 70:1615-1627.

9. Gaumy JL, Bailly JD, Benard G, Guerre P: Zèaralénone: origine et effets chez les animaux d'élevage. Revue Méd Vét 200I, I 52(2): $123-136$

10. Obremski K, Gajecki M, Zwierzchowski W, Zielonka L, OtrockaDomagala I, Rotkiewicz T, Mikolajczyk A, Gajecka M, Polak M: Influence of zearalenone on reproductive system cell proliferation in gilts. Pol J Vet Sci 2003, 6(4):239-245.

II. Gimeno A, Quintavilla JA: Analytical and mycotoxicological study of a natural outbreak of zearalenone mycotoxicosis in horse. Proceeding of International Symposium on Mycotoxins, National Research Centre: Cairo (Egypt) 1983:387-392.

12. Raymond SL, Smith TK, Swamy HVLN: Effects of feeding a blend of grains naturally contaminated with Fusarium mycotoxins on feed intake, serum chemistry, and hematology of horses, and the efficacy of a polymeric glucomannan mycotoxin adsorben. J Anim Sci 2003, 81 :21 23-2130.

13. Raymond SL, Smith TK, Swamy HVLN: Effects of feeding a blend of grains naturally contaminated with Fusarium mycotoxins on feed intake, metabolism and indices of athletic performance of exercised horses. J Anim Sci 2005, 83: I 267-I273.

14. Juhasz J, Nagy P, Kulcsar M, Szigeti G, Reiczigel J, Huszenicza G: Effect of low-dose zearalenone exposure on luteal function, follicular activity and uterine edema in cycling mares. Acta Vet Hung 200I, 49(2):2II-222.

15. Hochsteiner $W$, Schuh $M$ : Occurrence of the fusariotoxins deoxynivalenol and zearalenone in austrian feedstuffs in the period from 1995-1999. Dtsch Tierarztl Wochenschr 2001, I08:19-23.

16. Cecconi S, Ciccarelli C, Barberi M, Macchiarelli G, Canipari R: Granulosa cell-oocyte interactions. Eur J Obstet Gynecol Reprod Biol 2004, I I 5S:S19-S22.

17. Lacey M, Bohday J, Fonseka SMR, Ullah AI, Whitehead SA: Doseresponse effects of phytoestrogens on the activity and expression of $3 \beta$-hydroxysteroid dehydrogenase and aromatase in human granulosa-luteal cells. J Steroid Biochem $\mathrm{Mol}$ Biol 2005, 96:279-286.

18. Hsueh AJW, Billing H, Tsafriri A: Ovarian follicle atresia: a hormonally controlled apoptotic process. Endocr Rev 1994, I 5:707-724.
19. Guthrie HI, Welch GR, Couper BS, Zacaria AD, Johnson LA: Flow cytometric determination of degraded deoxyribonucleic acid in granulosa cells to identify atretic follicles during preovulatory maturation in the pig. Biol Reprod I994, 50: | 303- I 3 I I.

20. Blondin P, Dufour M, Sirard MA: Analysis of atresia in bovine follicles using different methods: flow cytometry, enzymelinked immunosorbent assay and classic histology. Biol Reprod 1996, 54:63 I-637.

21. Rosales-Torres AM, Avalos-Rodrìguez A, Vergara-Onofre $M$, Hernàndez-Pérez $O$, Ballesteros LF, Garcia-Macedo R, Ortiz-Navarrete $V$, Rosado A: Multiparametric study of atresia in ewe antral follicles: histology, flow cytometry, internucleosomal DNA fragmentation, and lysosomal enzyme activities in granulosa cells and follicular fluid. Mol Reprod Dev 2000, 55:270-28I.

22. Tajima K, Orisaka M, Hosokawa K, Amsterdam A, Kotsuji F: Effects of ovarian theca cells on apoptosis and proliferation of granulosa cells: changes during bovine follicular maturation. Biol Reprod 2002, 66:1635-1639.

23. Tsafriri A, Braw RH: Experimental approaches to atresia in mammals. Oxf Rev Reprod Biol 1984, 6:226-265.

24. Hinrichs K, Schmidt AL, Friedman PP, Selgrath JP, Martin MG: In vitro maturation of horse oocytes: characterization of chromatin configuration using fluorescence microscope. Biol Reprod 1993, 48:363-370.

25. Davidson TR, Chamberlain CS, Bridges TS, Spicer LJ: Effect of follicle size on in vitro production of steroids and insulin-like growth factor (IGF)-I, IGF-II and the IGF-binding proteins by equine ovarian granulosa cells. Biol Reprod 2002, 66: I640-1648.

26. Skorska-Wyszynska E, Jakimiuk E, Gajecka M, Mlynarczuk J, Obremski $\mathrm{K}$, Gajecki M: Preliminary evaluation of influence of zearalenone on cocultures of granulosa and internal theca cells of ovarian follicles in bitches in in vitro culture. Pol J Vet Sci 2004, 7(4):305-309.

27. Minervini F, Fornelli F, Flynn KM: Toxicity and apoptosis induced by mycotoxins nivalenol, deoxynivalenol and fumonisin $B$ I in a human erytroleukemia cell line. Toxicol in vitro 2004, I 8:2 I-20.

28. Penning TM, Burczynsli ME, Jez JM, Hung CF, Lin HK, Ma H, Moore M, Palackal N, Ratnam K: Human 3alpha-hydroxysteroid dehydrogenase isoforms (AKRI-AKRIC4) of the aldo-keto reductase superfamily: functional plasticity and tissue distribution reveals roles in the inactivation and formation of male and female sex hormones. Biochem J 2000, 35 I:67-77.

29. Malekinejad H, Van Toll HTA, Colenbrander B, Fink-Grenmels J: Expression of $3 \alpha$ and $\beta$-hydroxy steroid dehydrogenase mRNA in COCs and granulosa cells determines zearalenone biotransformation. Toxicol in vitro 2006, 20:458-463.

30. Takahashi M, Iwata N, Hara S, Mukai T, Takayama M, Endo T: Cyclic change in $3 \alpha$-hydroxysteroid dehydrogenase in rat ovary during the estrous cycle. Biol Reprod 1995, 53:|265-1270.

31. Pedersen HG, Watson ED, Telfer EE: Effect of ovary holding temperature and time on equine granulosa cell apoptosis, oocyte chromatin configuration and cumulus morphology. Theriogenology 2004, 62:468-480.

32. Pedersen HG, Watson ED, Telfer EE: Apoptosis in equine granulosa cells and its relationship to cumulus expansion and oocyte chromatin configuration in ovarian follicles. J Reprod Fertil 2000:455-462.

33. Quirk SM, Cowan RG, Harman RM, Hu C-L, Porter DA: Ovarian follicular growth and atresia: the relationship between cell proliferation and survival. J Anim Sci 2004, 82:40-52.

34. Quirk SM, Cowan RGm Harman RM: The susceptibility of granulosa cells to apoptosis is influenced by oestradiol and the cell cycle. J Endocrinol 2006, 189:44|-453.

35. Hay MR, Cran DG, Moor RM: Structural changes occurring during atresia in sheep ovarian follicles. Cell Tissue Res I 69(4):515-529. 1976 Jul 6

36. Yang MY, Rajamahendran R: Morphological and biochemical identification of apoptosis in small medium and large bovine follicles and the effects of follicle stimulating hormone and Insulin-like growth factor I on spontaneous apoptosis in cultured bovine granulosa cells. Biol Reprod 2000, 62:1209-1217.

37. Okolski A, Bezard J, Magistrini M, Palmer E: Maturation of oocytes from normal and atretic equine ovarian follicles as affected by steroid concentration. J Reprod Fertil 1991:385-392. 
38. Albrizio M, Dell'Aquila ME, Aiudi G, Cinone M, Lacalandra GM, Minoia P: Analysis of apoptosis in mural granulosa cells in the mare. In Proceeding. 3rd National Congress of Biotechnologies, I-3 July 1999 Consorzio Interuniversitario Biotecnologie. Urbino (Italy); 1999:33.

39. Dell'Aquila ME, Albrizio M, Maritato F, Minoia P, Hinrichs K: Meiotic competence of equine oocytes and pronucleus formation after intracytoplasmic sperm injection (ICSI) as related to granulosa cell apoptosis. Biol Reprod 2003, 68:2065-207.

40. Pedersen HG, Watson ED, Telfer EE: Analysis of atresia in equine follicles using histology, fresh granulosa cell morphology and detection of DNA fragmentation. Reproduction 2003, I 25:417-423.

4I. Powell DG, Troppman A, Tobin T, (Eds): Proceedings of the First Workshop on Mare Reproductive Loss Syndrome Section V, Mare Reproductive Loss Syndrome and Associated Syndromes: Toxicological Hypotheses University of Kentuki; 2003:59-75.

42. Newman K: Review of mycotoxins as a possible cause of mare reproductive loss syndrome. In Proceedings of the First Workshop on Mare Reproductive Loss Syndrome Edited by: Powell DG, Troppman A, Tobin T. Section V, Mare Reproductive Loss Syndrome and Associated Syndromes: Toxicological Hypotheses University of Kentuki; 2003:66-68.

43. Newman KE, Raymond SL: Effects of mycotoxins in horses. In The mycotoxin blue book Edited by: Diaz D. Nottingham University Press; 2005:57-76.

44. Alm H, Brussow KP, Torner H, Vanselow J, Tomek W, Danicke S, Tiemann U: Influence of Fusarium-toxin contaminated feed on initial quality and meiotic competence of gilt oocytes. Reprod Toxicol 2006, 22:44-50.

45. Tiermann U, Tomek W, Schneider F, Vanselow J: Effects of the mycotoxins $\alpha$ and $\beta$-zearalenol on regulation of progesterone synthesis in cultured granulosa cells from porcine ovaries. Reprod Toxicol 2003, 17:673-68I.

46. Minervini F, Dell'Aquila ME, Maritato F, Minoia P, Visconti A: Toxic effects of the mycotoxin zearalenone and its derivatives on in vitro maturation of bovine oocytes and $17 \beta$-estradiol levels in mural granulosa cell cultures. Toxicol in vitro 200I, 1 5:489-495.

Publish with Bio Med Central and every scientist can read your work free of charge

"BioMed Central will be the most significant development for disseminating the results of biomedical research in our lifetime. "

Sir Paul Nurse, Cancer Research UK

Your research papers will be:

- available free of charge to the entire biomedical community

- peer reviewed and published immediately upon acceptance

- cited in PubMed and archived on PubMed Central

- yours - you keep the copyright
BioMedcentral 